\title{
The Effect of Explicit Instruction of Connected Speech Features on Iranian EFL Learners' Listening Comprehension Skill
}

\author{
Moussa Ahmadian \\ Dept. of English Language and Literature, Faculty of Humanities, Arak University \\ Arak, 38156-8-8349, PO Box: 879, Iran \\ Tel: +988633135111, E-mail: M-ahmadian@araku.ac.ir; Moussa_ahmadian@yahoo.co.uk \\ Riyadh Matour (Corresponding Author) \\ Dept. of English Language and Literature, Faculty of Humanities, Arak University \\ Arak, 38156-8-8349, Iran \\ Tel: 98-9166301193,E-mail: riadhmatour@yahoo.com
}

Received: 22-11-2013

doi:10.7575/aiac.ijalel.v.3n.2p.227
Accepted: 01-01-2014

Published: 01-03-2014

\begin{abstract}
Listening comprehension has found its right place in the field of SLA in recent decades. For years, among all language skills, speaking and writing were of high significance in teaching and learning a new language as they were considered to be productive skills. Listening and reading, on the other hand, were neglected since they were regarded as passive skills, means to other ends, rather than ends in themselves. This study investigates possible effects of explicit instruction of connected speech features on listening comprehension of Iranian English language learners. Forty adult female Persian speaking homogeneous English learners, aged 18-30, participated in the study. They were divided into two experimental and control groups. The experimental group received explicit instructions on connected speech features, while the control group followed the routine instructions designed by their institute. Tests of connected speech features were used in pre- and post tests. The participants' scores on the pre-posttests were compared via the paired samples ttests and independent samples t-tests. The results indicated the outperformance of the experimental group over the control group, thus, suggesting that explicit instructions of connected speech features have facilitative roles in improving EFL learners' listening comprehension skill. Possible implications of the findings for teaching listening comprehension are discussed.
\end{abstract}

Keywords: connected speech features, reduced forms, listening comprehension, implicit instruction, explicit instruction, language skills

\section{Introduction}

People hold different attitudes toward learning a new language. Some argue that learning a language is speaking and writing in the given language, whereas others believe that listening and reading are worth considering as well (Rost, 1994). For a long time, among the four language skills, speaking and writing were of high importance in learning a new language owing to the fact that they were regarded as productive skills. Listening and reading, on the other hand, bore the dust of negligence as they were considered to be passive or secondary skills, means to other ends, rather than ends in themselves (Nunan, 1997).

Research relating to listening comprehension has identified many problems which might pose some difficulties for the learners (Brown, 1990; Cauldwell, 2003; Field, 2003). There exist many problems for non-native speakers when learning a new language. One of the greatest challenges for non-native learners of English is to perceive, recognize and understand rapid, fluent speech, typical of native speakers. According to Campbell, Meinardi, Richardson, and Macdonnell (2007, p. 5), the problem is thus three-fold:

1. Native English speech features, namely elision, assimilation and weak forms, cause aural and processing problems for EFL/ESL learners,

2) Current classroom listening techniques fail to adequately address such problems, and

3) There is a lack of comprehensive pedagogical model to train students to 'listen as native speaker does'.

Regarding the first problem mentioned above, English learners should bear in mind that typical native English speech usually tends to be fast and fluid, including connected speech features such as contraction, intrusion, elision, assimilation, and weak forms (Ur, 1984; Brown, 1990; Cauldwell, 2003; Field, 2003). While most English native speakers have little or no difficulty in understanding such speech, non-native speakers might feel linguistically overburdened, frustrated, and agonized when taking a listening exercise or communicating with native speakers. This is, 
to some extent, due to the fact that in an EFL/ESL listening class, learners are constantly exposed to deliberate speech which almost resembles citation forms. Teachers tend to meet students' level of understanding by using simple structures and enunciating their speech distinctly. Although this strategy is carried out for the purpose of facilitating the process of language learning, it cannot be regarded as an adequate pattern of native English speech. In a real language use, sentences undergo very complicated procedures which result in considerable phonological alterations such as contractions, deletions, assimilations..... . Consequently, EFL/ESL learners might be ill-equipped to deal with natural native English conversation when they encounter a real situation in spite of having been attending English classes for a long time. According to Brown (1990):

Students whose education has been largely couched in slowly and deliberately spoken English are often shocked to find, when they enter a context in which native speakers are talking to each other, that they have considerable difficulty in understanding what is being said (p. 6).

Ur (1984) claims that the main focus of most English classes is devoted to introducing words in isolation which are presented in their citation forms. Therefore, learners find less opportunity to get acquainted with the weak forms of words when used in a natural speech. Needless to say, the language used in a real life is quite different from that of classroom setting in EFL education. In a typical conversation, depending on the significance of a message, native speakers tend to stress some words and leave some unstressed. Learners should be aware of this strategy and they should try to put it into practice whenever they have a conversation. Moreover, knowing the fact that the stressed words usually carry the essence of a message would help the learners cope with the burden of the whole words by being selective in paying attention to some part of a message and leaving the rest out of focus. Regarding the significance of slow speech for learners in the very beginning of learning English, Brown (1990) argues that "in the early stages, while the student is still struggling with an unfamiliar sound system, not to mention exotic syntactic and lexical forms, this (carefully and slowly enunciated speech) is clearly the only practicable approach" (p. 158). To sum it up, many people have claimed the importance of listening comprehension in general and connected speech features (reduced forms) in particular in learning a new language (Call, 1985; Rost, 1994; Lynch, 1998; Weinstein, 2001; Rosa, 2002; Cauldwell, 2003, Field, 2003; Brown, 2006; Matsuzawa, 2006; Carreira, 2008). Nevertheless, in spite of the importance of listening comprehension in L2 teaching and learning, the sketch of which mentioned above, little research has been reported to focus on the effects of explicit teaching of connected speech features on learners' listening comprehension ability. This paper, thus, aims to investigate the possible effects and to shed some light on this crucial point.

\section{Review of related literature}

Nowadays, one can say that listening is well regarded as a pivotal and independent skill, well- attended to, listening can pave the way for intelligible or native-like speaking. As Rost (1994) argues, listening is vital in the language classroom since it provides input for the learners. Without making sense of the input at the right level, no learning can simply begin. Listening is thus fundamental to language learning in general, and to speaking in particular. Rost (1994) provides three other important reasons for giving prominence to listening, and demonstrates the importance of listening to the development of spoken language proficiency. These three reasons are as follows:

Spoken language provides a means of interaction for the learner. Because learners must interact to achieve understanding, access to speakers of the language is essential. Moreover, learners' failure to understand the language they hear is an impetus, not an obstacle, to interaction and learning. Authentic spoken language presents a challenge for the learner to attempt to understand language as native speakers actually use it. Listening exercises provide teachers with the means for drawing learners' attention to new forms (vocabulary, grammar, new interaction patterns) in the language (pp. 141-142).

The fact that listening has been overlooked or poorly taught might have premised on the assumption that it is a passive skill and that merely exposing students to the spoken language provides adequate instruction in listening comprehension (Call, 1985). The significance of listening comprehension skill as an active skill was recognized when many schools of thought contributed to reintroducing this skill as an independent one. Among many schools of thought, the one which had remarkable impacts on teaching was the Behavioral approach which drew inspiration from Pavlov's conditioning experiments, and particularly Skinner's (1957) 'operant conditioning. From Behaviorists vantage, language is considered to be a fundamental part of total human behavior. A behaviorist tends to be of the idea that effective language behavior should be the production of correct responses to stimuli. Language development was thought to be accounted for by the same token; languages are ultimately finite entities and might be learned through imitation and practice. This traditional approach to listening which was highly production oriented "has trapped students in a frenzied 'hear it, repeat it!', 'hear it, answer it!, or 'hear it, translate it' nightmare” (Meyer, 1984,p. 343).

What make listening comprehension different from other skills are the perplexing processes involved. Listeners might come across some phonological modifications including contraction, assimilation, elision, intrusion, which are often made based on a set of very complex rules which play a pivotal role in imposing certain problems on listeners by making the task of comprehension really tough, if not, impossible. Lynch (1998) maintains that research into listening over the past three decades has, above all, placed emphasis on the fundamental intricacy of the processes involved. In order for listeners to make sense of delivered speech, they may need to integrate information from a range of sources: phonetic, phonological, prosodic, lexical, syntactic, semantic, and pragmatic. Lund (1991) states that one unique 
characteristic of listening comprehension is that "it exists in time, rather than space - it is ephemeral in nature" and that "the sound system of the second language poses a significant problem" (p. 201). This could be one of the reasons why listening comprehension skill has not received special attention as an independent skill. Teachers often expect students to develop their listening skill by sheer exposure to the target language all day and without help (Mendelssohn, 1984; Oxford, 1993). One, as an English teacher, should try to get well acquainted with the complicated process involved in listening comprehension before embarking on teaching it.

In addition to what mentioned regarding the significance of listening comprehension, there exists one factor which plays a significant role in listening skill and is of paramount importance for the present study. The complexity of listening comprehension as a result of features of "connected speech "interference has been investigated in many studies showing how this phenomenon might bring about frustration on the part of examinee when trusted with listening comprehension task (Henrichsen, 1984; Brown and Hilferty, 1986a,1986b ; Ito, 2006a ).

The term connected speech or reduced forms have been defined by many scholars. Brown and Hilferty (1986a) use the term "reduced forms" to refer collectively to the processes of contraction, elision, assimilation, and reduction (e.g., there's, coulda, wanna, and howarya for "there is," "could have," "want to," and "how are you," respectively). According to Weinstein (2001), reduced forms are the spontaneous pronunciation changes in adjacent words or sounds spoken at a natural speed. Rosa (2002) suggests that these forms are a common element of spoken English, found in all registers and all rates of speech. Brown and Kondo-Brown (2006) define connected speech as an "analysis of the continuous chains in normal spoken language and conversation as compared with the typical linguistic analysis of individual phonemes analyzed in isolation" (p. 284). They mention that connected speech makes up "a very real part" (p. 5) of the spoken language and occurs in "all levels of speech" (p. 5) from casual to even very formal levels.

Brown (2006, p.15) has identified nine processes underlying connected speech; they are:

1) Word stress: which refers to the degree of force used in producing a syllable, as identified from unstressed words

2) Sentence stress and timing: which is by definition the pattern of stress or syllable timing in the stress groups in a sentence (or utterance) of the language.

3) Reduction: A process that occurs in connected speech, wherein the phonemes of a language are changed, minimized, or eliminated in order to make pronunciation easier

4) Citation and weak forms of words, which refer to the pronunciation of words in a language depending on the context in which they are found. A word may be pronounced in one way when it is prominent and in another when it is not. (e.g. some $/ \mathrm{s}^{\wedge} \mathrm{m} /$ and $/ \mathrm{s} ə \mathrm{~m} /$ ).

5) Elision: This connected speech process involves dropping either vowels or consonants that would otherwise be present in the citation form of a word or phrase. Elision is a very frequent process in connected speech, especially in the weak forms

6) Intrusion: as opposite to elision, because it involves inserting phonemes within or between words rather than dropping them (e.g. I saw (r) him yesterday).

7) Assimilation: a common connected speech process during which a sound becomes similar to an adjacent sound (e.g. "could have = coulda").

8) Juncture: This is a connected speech process that describes how neighboring phonemes are connected. (e.g. my train vs. might rain, night rate vs. nitrate).

9) Contraction: a written manifestation of a small set of connected speech processes, often used in written dialogue to give a spoken flavor, (e. g. I'm, don't, she's, they'll, we're, you'd, etc).

There exist a number of reasons which contribute to the significance of connected speech in learning a new language, making teachers and instructors consider these features of high significance to be included in their teaching program. First of all, native speakers customarily tend not to pause between each word, rather, they move from one word to the next by drawing sounds together. Secondly, while talking, native speakers of English are selective in putting emphasis on some words and leaving some others unstressed. That is, not all syllables are equal. The strong syllables which carry the essence of the message are usually stressed and lengthened while the week ones are almost left out, if not, they cannot be heard. As a result, sentences tend to be relatively "elastic" (Kenworthy, 1987, p. 17). Furthermore, research studies indicate that non-native speakers have problems in understanding or producing the features of connected speech (Henrichsen, 1984; Brown and Hilferty, 1986a, 1986b). Research also indicates that the elements of connected speech can be taught to non-native speakers of English (Brown and Hilferty, 1986a, 1986b). In some cases, the simple awareness of their existence can help enormously in enabling students to better understand the language they hear. As Brown (2006) argues, students need to be able to adapt their styles and registers in using language, and the ability to understand and use connected speech is necessary for these adaptations.

To sum up, due to the fact that "connected speech" features are unquestionably regarded as an integral part of every language, the role of their explicit instruction on the development of L2 listening comprehension skill has not been touched upon satisfactorily in instructed SLA and classroom activities. This study thus was designed to address the problem and to shed some light on this point. 


\section{Method}

The present study investigates the effect of explicit instruction of connected speech features (reduced forms) on listening comprehension of Iranian EFL learners. In this regard, the study attempts to answer the following question:

-- Does explicit instruction of “connected speech" features affect Iranian EFL learners' listening comprehension?

To be more objective, the following null hypothesis was formulated to be tested out:

-- Explicit instruction of “connected speech features" does not affect Iranian EFL learners' listening comprehension.

\subsection{Participants}

Participants were 40 female Persian speaking homogeneous EFL learners, aged 18-30, who were selected from among a pool of 80 ones and asked to participate in the experiment. Their homogeneity was measured through Top Notch Test, developed and validated by their language institute. They were intermediate learners who attended English classes at Alale English Institute of Mahallat, Iran.

Having taken the Top Notch proficiency test, the participants were randomly assigned to two experimental and control groups, each comprising 20 participants. The experimental group received various types of connected speech or reduced forms instructions, whereas the control group followed the institute language programs which centered around the speaking skill, that is, listening was not the main concern of teaching plan and it was taught implicitly. The class met 3 sessions per week, 75 minutes each session for a term of 23 sessions.

\subsection{Materials}

For testing listening ability, the most dominant forms that were proposed and used in research were different variations of dictation or cloze style tests which required students to listen to sentences articulated with connected speech forms and fill in the blanks with their citation forms (Henrichsen, 1984; Brown \& Hilferty, 2006; Ito, 2006a; Matsuzawa, 2006). Another form useful for assessing listening comprehension is a test where the examinees would have to answer comprehension questions after listening to a passage or dialogue filled with connected speech features (Brown \& Kondo-Brown, 2006).

The main source of features of connected speech used in this study was David Brett's website which is mainly concerned with English phonetics and phonology followed by plenty of exercises and tests. In addition, two other textbooks, "Tune In" by J.C. Richards \& K.O.Sullivan and "Steps to Understanding" by L.A. Hill, were worked on during the course in order to reinforce the treatment and provide the learners with some exposure to "connected speech features". As the learners were intermediate, "Tune In" level 3 and Steps to Understanding (intermediate part) were chosen. Different reading passages which were taken from the site of Learn English at British Council were given to the learners with the purpose of listening to the passages and trying to answer the questions.

\subsection{Procedures}

As mentioned earlier, the main source of features of connected speech used as tests in this study was David Brett's website. In order to discover the appropriateness and reliability of the given site, the researchers had the abovementioned tests piloted with a group of 20 learners of the same proficiency level as the target group. Once the reliability of the pilot test was approved, the two groups took a pretest of listening comprehension consisting of thirty questions. The questions were on connected speech features in the form of pen and paper. Learners were asked to listen to each sentence which had some parts related to reduced forms missing as blanks; each sentence was repeated three times. The subjects were to fill in the blanks to complete the forms of features of connected speech which were pronounced in reduced form (e.g. gonna, going to).

Following the pretest, the experimental group was provided with some general information about the significance of connected speech features and the role they play in listening comprehension. The experimental group received instructions on Weak Forms, Assimilation of Place of Articulation, Yod Coalescence, Gap filling exercise on Yod Coalescence, Elision, Assimilation of Voicing, and R-linking during the course, while the control group was taught the routine instruction of the institute.

\subsection{Data Analysis and Results}

The two groups' scores on the tests were calculated and compared using t-tests. Doing this ${ }_{2}$ an Independent-Samples ttest procedure was used to see whether there exists any significant difference in the performance of the two groups on each test. The results are as follows.

\subsubsection{Descriptive Statistics}

Descriptive statistics was computed for the experimental and control groups' performance on both pre-tests and posttests. Table 1 displays the results. 
Table 1. Results of the Descriptive Statistics for Pretests and Posttests of the Experimental and Control Groups

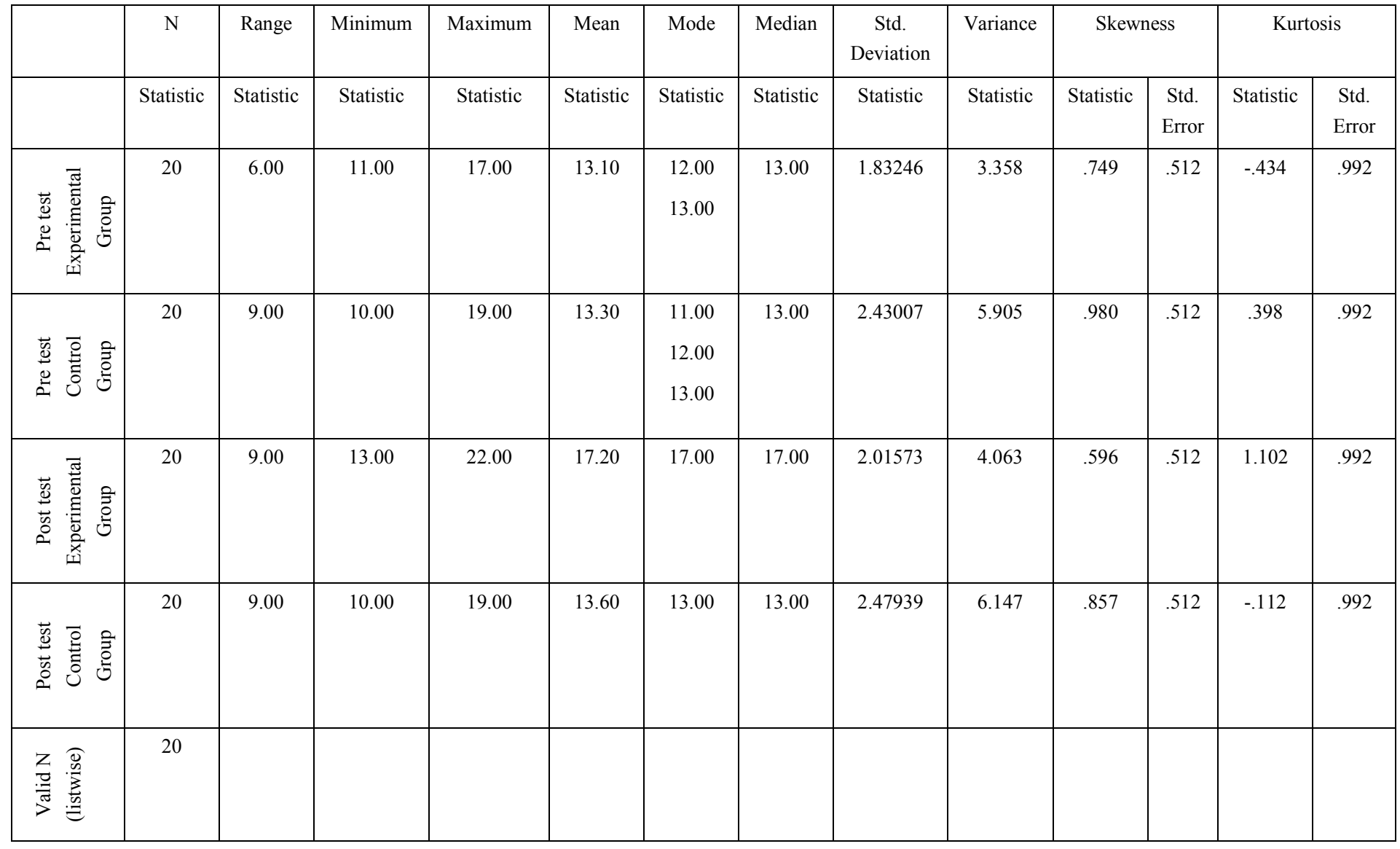

According to Table 1, the mean score of the experimental group in the pretest is 13.10 and in the posttest is 17.20 , while that of the control group in the pre test is 13.30 and in the posttest is 13.60 . The comparison of the mean scores of the two groups in the pre tests shows that both groups have close mean scores. However, the mean scores of the two groups in the posttest are different, that is, the experimental group $(M=17.20)$ outperformed the control group $(M=13.60)$ in the posttest.

Table 1 also provides two more pieces of information on the normality of the distribution of scores in pretests and posttests. The estimated median and mode for pretest in the experimental group are 12.00, 13.00, and 13.00. For the control group, the mode and median are 11.00,12.00, 13.00, and 13.00, respectively. For posttest of the experimental group, the mode and median are 17.00 and 17.00, and for the control group, the mode and median are 13.00 and 13.00 . It seems that the mode and median of the pretest and posttest of both the experimental and the control groups are to a large extent the same, which shows a rather normal distribution.

\subsection{Group Comparisons}

In order to see whether teaching of connected speech features leads to improving learners' perception, the two groups were compared after treatments. Two kinds of comparisons were done: Within-group - the experimental group in preposttests and the control group pre-posttest, and Between-group comparisons - the two groups in the pre-test, and the two groups in the posttest.

\section{5. 1 Within-group Comparisons: paired-samples t-test}

The statistical analyses relevant to the present study were done through paired-samples t-tests for the pretest and posttest of the experimental group. Tables 2 and 3 illustrate the results.

Table 2. Paired Samples Statistics for the Pretest and Posttest of the experimental group

\begin{tabular}{|c|c|c|c|c|c|}
\hline & & Mean & $\mathrm{N}$ & Std. Deviation & Std. Error Mean \\
\hline \multirow[b]{2}{*}{ Pair 1} & Pre test Experimental Group & 13.1000 & 20 & 1.83246 & .40975 \\
\hline & $\begin{array}{l}\text { Post test Experimental } \\
\text { Group }\end{array}$ & 17.2000 & 20 & 2.01573 & .45073 \\
\hline
\end{tabular}


Table 3. The Results of Paired Samples T-Test for the Pretest and Posttest of the Experimental Group

Paired Differences

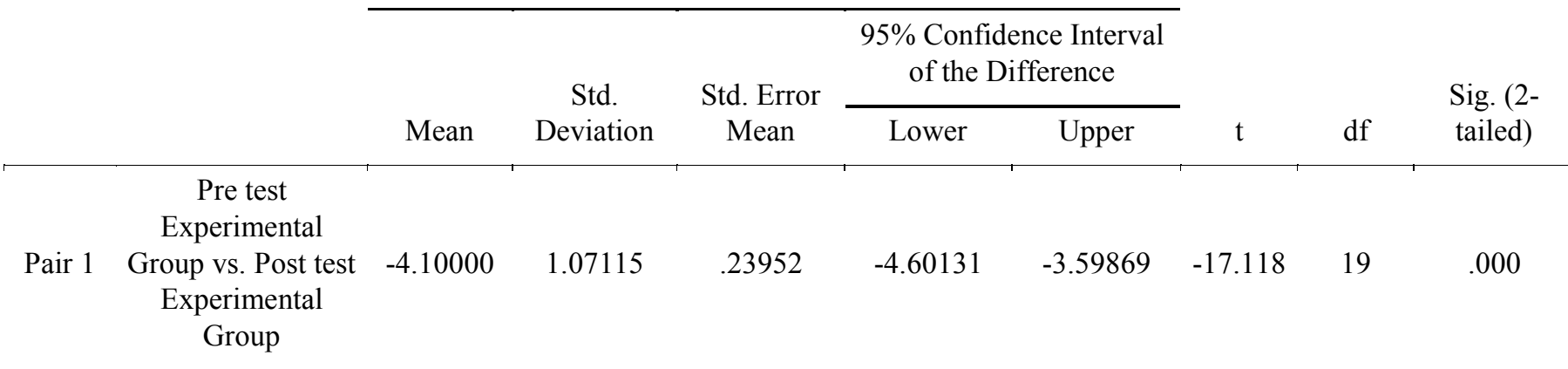

Level of significance: $p<.05$

According to Tables 2 and 3, there was a statistically significant difference in the experimental group's performance on the perception test from pretest $(M=13.10, S D=1.83)$ to posttest $(M=17.20, S D=2.01), \mathrm{t}(19)=-17.11, p<.05$ (twotailed). The mean decrease in learners' scores was -4.1 with a $95 \%$ confidence interval ranging from -4.60 to -3.59 . The eta squared statistic (19) indicated a large effect size according to Cohen's (1988, cited in Pallant, 2007) guideline for interpreting the effect size (i.e., .01=small effect, .06=moderate effect, and .14=large effect). Tables 4 and 5 show the results of the statistical analyses carried out for the control group.

Table 4. Paired Samples Statistics Test for the Pretest and Posttest of the Control Group

\begin{tabular}{cccccc}
\hline & Mean & $\mathrm{N}$ & Std. Deviation & Std. Error Mean \\
\hline \multirow{2}{*}{ Pair 1 } & Pre test Control Group & 13.3000 & 20 & 2.43007 & .54338 \\
& Post test Control Group & 13.6000 & 20 & 2.47939 & .55441 \\
\hline
\end{tabular}

Table 5. The Results of Paired Samples T-Test for the Pretest and Posttest of the Control Group

\begin{tabular}{|c|c|c|c|c|c|c|c|c|c|}
\hline & & \multicolumn{5}{|c|}{ Paired Differences } & \multirow{3}{*}{$\mathrm{t}$} & \multirow{3}{*}{$\mathrm{df}$} & \multirow{3}{*}{$\begin{array}{l}\text { Sig. }(2- \\
\text { tailed) }\end{array}$} \\
\hline & & \multirow[t]{2}{*}{ Mean } & \multirow{2}{*}{$\begin{array}{c}\text { Std. } \\
\text { Deviation }\end{array}$} & \multirow{2}{*}{$\begin{array}{l}\text { Std. Error } \\
\text { Mean }\end{array}$} & \multicolumn{2}{|c|}{$\begin{array}{c}95 \% \text { Confidence Interval } \\
\text { of the Difference }\end{array}$} & & & \\
\hline & & & & & Lower & Upper & & & \\
\hline Pair 1 & $\begin{array}{l}\text { Pre test Control } \\
\text { Group - Post test } \\
\text { Control Group }\end{array}$ & -.30000 & 1.26074 & .28191 & -.89005 & .29005 & -1.064 & 19 & .301 \\
\hline
\end{tabular}

Level of significance: $p=.05$

Based on Tables 4 and 5, there was not any statistically significant difference in the control group's performance on the perception test from the pretest $(M=13.30, S D=2.43)$ to the posttest $(M=13.60, S D=2.47), \mathrm{t}(19)=-1.06, p=.30$ (two-tailed). The mean decrease in learners' scores was -.3 with a $95 \%$ confidence interval ranging from -.89 to .29 . The eta squared statistic (.05) indicated a small effect size according to Cohen's (1988 cited in Pallant, 2007) guideline for interpreting the effect size (i.e., .01 = small effect, .06 = moderate effect, and .14 = large effect).

\subsubsection{Between Group Comparisons: Independent-samples t-test}

An independent samples t-test was also run to compare the mean scores of the pretests and posttests of the experimental and control groups. The results of the independent samples t-test on the pretests of the two groups are presented in Tables 6 and 7 .

Table 6. Group Statistics (Pretests of the Experimental and Control Groups)

\begin{tabular}{cccccc}
\hline & pretest & $\mathrm{N}$ & Mean & Std. Deviation & Std. Error Mean \\
\hline \multirow{3}{*}{ prexpcont } & pre experimental & 20 & 13.1000 & 1.83246 & .40975 \\
& pre control & 20 & 13.3000 & 2.43007 & .54338 \\
\hline
\end{tabular}


Table 7. The Results of the Independent Samples T-Test for Pretests of the Experimental and Control Groups

\begin{tabular}{|c|c|c|c|c|c|c|c|c|c|c|}
\hline & & \multicolumn{2}{|c|}{$\begin{array}{c}\text { Levene's Test for } \\
\text { Equality of } \\
\text { Variances }\end{array}$} & \multicolumn{7}{|c|}{ t-test for Equality of Means } \\
\hline & & \multirow[t]{2}{*}{$\mathrm{F}$} & \multirow[t]{2}{*}{ Sig. } & \multirow[t]{2}{*}{$\mathrm{t}$} & \multirow[t]{2}{*}{ df } & \multirow[t]{2}{*}{$\begin{array}{l}\text { Sig. (2- } \\
\text { tailed) }\end{array}$} & \multirow[t]{2}{*}{$\begin{array}{c}\text { Mean } \\
\text { Difference }\end{array}$} & \multirow[t]{2}{*}{$\begin{array}{l}\text { Std. Error } \\
\text { Difference }\end{array}$} & \multicolumn{2}{|c|}{$\begin{array}{l}95 \% \text { Confidence } \\
\text { Interval of the } \\
\text { Difference }\end{array}$} \\
\hline & & & & & & & & & Lower & Upper \\
\hline \multirow{2}{*}{ prexpcont } & $\begin{array}{c}\text { Equal variances } \\
\text { assumed }\end{array}$ & 1.220 & .276 & -.294 & 38 & .770 & -.20000 & .68056 & -1.57772 & 1.17772 \\
\hline & $\begin{array}{c}\text { Equal variances } \\
\text { not assumed }\end{array}$ & & & -.294 & 35.328 & .771 & -.20000 & .68056 & -1.58115 & 1.18115 \\
\hline
\end{tabular}

According to Table 7, the Sig. value for Leven's test is .27. This is larger than the cut-off of .05. This means that the assumption of equal variances has not been violated. To find out whether there was a significant difference in the pretest scores of the experimental and control groups, it is necessary to refer to the first row and the column labeled Sig, ( 2 tailed). Since the Sig. value is above .05, there is no significant difference in the pretest scores for the experimental group $(M=13.10, S D=1.83)$ and the control groups $(M=13.30, S D=2.43) ; t(38)=-.29, p=.77$. The mean decrease in learners' scores was -.2 with a $95 \%$ confidence interval ranging from -1.57 to 1.17 . Further, the eta squared statistic (.002) indicated a small effect size.

Another independent samples t-test was run to compare the mean scores of the posttests of the experimental and control groups. The results are presented in Tables 8 and 9.

Table 8. Group Statistics (Posttests of the Experimental and Control Groups)

\begin{tabular}{cccccc}
\hline & Post test & $\mathrm{N}$ & Mean & Std. Deviation & Std. Error Mean \\
\hline \multirow{2}{*}{ postexpcont } & post experimental & 20 & 17.2000 & 2.01573 & .45073 \\
& post control & 20 & 13.6000 & 2.47939 & .55441 \\
\hline
\end{tabular}

Table 9. The Results of the Independent Samples T-Test for Posttests of Experimental and Control Groups

\begin{tabular}{|c|c|c|c|c|c|c|c|c|c|c|}
\hline & & \multicolumn{2}{|c|}{$\begin{array}{c}\text { Levene's Test for } \\
\text { Equality of } \\
\text { Variances }\end{array}$} & \multicolumn{7}{|c|}{ t-test for Equality of Means } \\
\hline & & \multirow[t]{2}{*}{$\mathrm{F}$} & \multirow[t]{2}{*}{ Sig. } & \multirow[t]{2}{*}{$\mathrm{t}$} & \multirow[t]{2}{*}{ df } & \multirow[t]{2}{*}{$\begin{array}{l}\text { Sig. (2- } \\
\text { tailed) }\end{array}$} & \multirow[t]{2}{*}{$\begin{array}{c}\text { Mean } \\
\text { Difference }\end{array}$} & \multirow[t]{2}{*}{$\begin{array}{l}\text { Std. Error } \\
\text { Difference }\end{array}$} & \multicolumn{2}{|c|}{$\begin{array}{l}95 \% \text { Confidence } \\
\text { Interval of the } \\
\text { Difference }\end{array}$} \\
\hline & & & & & & & & & Lower & Upper \\
\hline \multirow{2}{*}{ postexpcont } & $\begin{array}{c}\text { Equal variances } \\
\text { assumed }\end{array}$ & 1.673 & .204 & 5.038 & 38 & .000 & 3.60000 & .71451 & 2.15355 & 5.04645 \\
\hline & $\begin{array}{c}\text { Equal variances } \\
\text { not assumed }\end{array}$ & & & 5.038 & 36.480 & .000 & 3.60000 & .71451 & 2.15157 & 5.04843 \\
\hline
\end{tabular}

Based on Table 9, the Sig. value for Leven's test is .20. This is larger than the cut-off of .05. This means that the assumption of equal variances has not been violated. To find out whether there was a significant difference in the posttest scores for the experimental and control groups, it is necessary to refer to the first row and the column labeled Sig, (2 tailed). Since the Sig. value (.000) is less than .05, it can be concluded that there exists significant difference in posttest scores for the experimental $(\mathrm{M}=17.20, \mathrm{SD}=2.01)$ and control groups $(\mathrm{M}=13.60, \mathrm{SD}=2.47), \mathrm{t}(38)=5.03, p<$ .0005. The mean decrease in learners' scores was 3.6 with a $95 \%$ confidence interval ranging from 2.15 to 5.04 . Further, the eta squared statistic (.39) indicated a large effect size. Figure (1) shows all the results of comparison of the two groups' scores in the pre-posttests. 


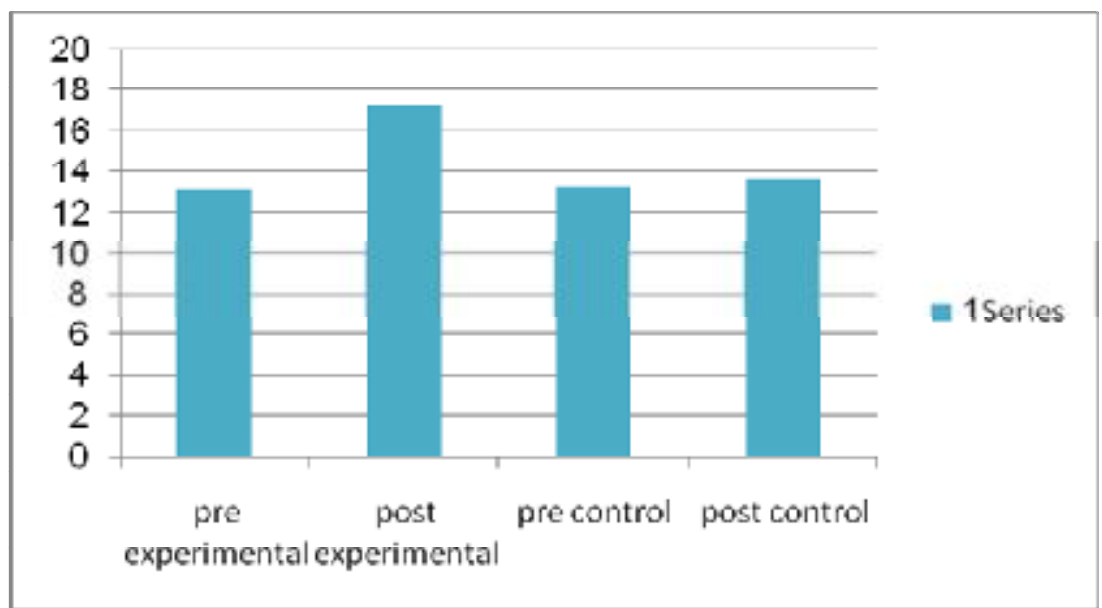

Figure 1. Total comparisons between the Control and the Experimental Groups in the Pretest and Posttest Scores

As illustrated in Figure 1, the two groups have almost equal performance in the pretests. In the posttests, however, the experimental group showed a better performance than the control group. Moreover, the comparisons between pretest and posttest of the experimental group suggests that the performance of the experimental group was better after the treatment, while no remarkable difference was seen in the posttest scores of the control group after the treatment.

\section{Discussion}

The main purpose of this research was to discover whether explicitly teaching features of connected speech or reduced forms could facilitate learners' listening comprehension skill. Based on the results of data analyses presented above, one could observe ostensible progress in the experimental group's performance after receiving instruction on connected speech features. While, there was not any statistically significant difference in the control group's performance (Tables 4.5). Thus, the null hypothesis which states that the explicit instruction of connected speech features does not affect learners' listening skill is rejected and the research question can be answered; that is, explicit teaching of reduced forms has positive effects on L2 learners' listening skill.

According to some research, the elements of connected speech features can be taught to non-native speakers of English (Brown and Hilferty, 1986a, 1986b, 2006). Furthermore, it is argued that the simple awareness of connected speech features existence in a typical conversation can be of great help in enabling learners to better understand the language they hear (Field, 2003). Field contends that teachers should inform their students about the features of fast spontaneous speech (p. 327). He also suggests methods for EFL/ESL learners to overcome these features, notably, 'to be aware of them and to be prepared to practice them (p. 332). The findings of the present study correspond to that of Williams (1999) who investigated whether learners are able to induce grammatical rules from exposure to input when their attention is focused on meaning and found that learning does take place. Williams (1999) mentioned that the learners in his study 'had high levels of awareness of the product of learning' (p. 38; see also, Williams, 2005; Williams \& Lovett, 2003).

Brown (1990) argues that it is of utmost importance that teachers help learners develop their listening skill and move beyond deliberate and slow speech to more natural forms, which will enable them to cope with streamed speech as it is naturally spoken by English native speakers. During the observations, the subjects in the present study were asked to express their opinions regarding the effectiveness of the course of instructions on connected speech features. They commented that the course was of high help to them since they could be exposed to these features and learn them as prefabricated expressions. The subjects also commented that before receiving any instruction on these forms they used to pay attention to each word they came across while practicing listening exercises. It could be concluded that learning the reduced forms as prefabricated expressions along with weak forms could help learners cope with streamed speech when delivered rapidly in a typical conversation.

The findings of this research also support Leow's (1997) findings, who asked beginner learners of L2 Spanish to think aloud as they completed a crossword which exposed them to a number of morphological forms. Learning was measured by means of a multiple choice recognition task and a fill-in-the-blank written production task. Leow reported that the level of awareness learners demonstrated correlated with both their ability to recognize and produce correct target forms. Rosa and O'Neill (1999) replicated Leow's (1997) findings; learners who demonstrated high awareness during learning outperformed those with low awareness. The subjects' scores on the explicit teaching in the present study showed a drastic change from the pretest and posttest as well, supporting the effects of such kind of instructions. Our findings are also in line with Brown and Hilferty's ( 2006) who investigated the teachability and effectiveness of explicit instruction of connected speech on listening comprehension with 32 Chinese EFL learners, and concluded that teaching connected speech does facilitate comprehension development. Matsuzawa (2006) and Carreira (2008) came also to some similar findings. All in all, based on the findings of the present study, the research question can be answered that treatments of connected speech features have positive effects on and facilitates L2 Iranian English learners' listening comprehension ability. 


\section{Conclusions \& Implications}

The results of the present research highlighted the role of explicit instruction of connected speech features in developing listening comprehension skill. As Rost (1994) points out, listening is vital in the language classroom since it provides input for the learners. Owing to the fact that "connected speech" features are unquestionably regarded as an integral part of every language, it should be addressed and dealt with in every classroom setting. No need to say that teachers can play essential roles in providing their learners with some listening strategies and constant support and, if left high and dry, learners would not find their way out through the labyrinth of language learning. Teachers need to be aware of what high frequency reduced forms occur in spoken English before setting out to give students practice on recognizing them and should try to raise their students' awareness about the existence of connected speech features in ordinary speech.

The findings might benefit language teachers and practitioners, and language learners. Perhaps the first experts in language teaching who could benefit from the findings of this study are teachers. Drills and repetition exercises have fewer places in teaching listening comprehension skill since less can they provide the learners with authentic input. Many scholars have recognized the problems which non-native speakers of English might encounter in listening comprehension as a result of connected speech features (Field, 2003; Brown and Hilferty, 2006; and Ito, 2006a). Accordingly, with explicit instruction of connected speech features or reduced forms, teachers might reduce the difficulty which the learners face in listening comprehension. Teachers can raise their students' attention to these features and they can provide their learners with some techniques to facilitate their understanding. They should also know that in order for the learners to become good listeners and gain a good command in listening, it is advisable to teach them the complicated process involved in a natural conversation and let them have some listening practices.

The findings can also help learners of English in general. Learners can learn these features and try to make use of them while speaking so that they can enhance their overall intelligibility and sound more native-like while speaking English. Learning features of connected speech could help learners become more active and gain more confidence when taking part in class activity. Some learners prefer not to participate in discussion held in class regarding different topics. One reason behind this decision might have something to do with weak pronunciation or strong accent that some learners possess. These learners decide to keep silent instead of joining the talk, afraid of being mocked because of their weak pronunciation or strong accent. Therefore, language learners may presumably increase their confidence by learning these features and they can also become active participants in classroom.

The findings suggest some clues and guidelines to help syllabus designers and textbooks writers to look at listening comprehension skill from a new standpoint. That is, listening skill should involve teaching connected speech features as an integral part. Field (2003) argues that teachers use listening activities to serve other language skills, such as discussion and writing task, rather than only listening skill and he calls for a change in listening pedagogy. Norris (1995) argues that many of the listening materials on the market today do not resemble the natural speech carried out by English native speakers and are mainly concerned with helping learners practice "top-down" skills. Typical questions following each lesson in listening would be some general questions which require learners to find names, places, and numbers. In addition, students are often provided by a list of vocabulary with their "citation forms" and scant attention is paid to the phonological characteristics that mark informal speech. As Norris puts it, this seems a bit like "putting the cart before the horse". So it can be concluded that practical and authentic exercises regarding teaching connected speech features could be included in the syllabus to highlight the significance of these features in teaching and developing L2 learners' listening skill, and their speaking ability as well.

\section{References}

Brown, G. (1990). Listening to spoken English, 2nd (ed). London: Longman.

Brown, J. D. (2006). Authentic communication: Whyzit important' ta teach reduced forms? University of Hawai'i at Manoa.

Brown, J. D., \& Hilferty, A. (1986a). Listening for reduced forms. TESOL Quarterly, 20(4), 759-763.

Brown, J. D., \& Hilferty, A. (1986b). The effectiveness of teaching reduced forms for listening comprehension. RELC Journal, 17(2), 59-70.

Brown, J. D., \& Hilferty, A. (2006). The effectiveness of teaching reduced forms for listening comprehension. In J. D. Brown, \& K. Kondo-Brown, (Eds.), Perspectives on Teaching Connected Speech to Second Language Speakers (pp. 51-58). Honolulu, HI: University of Hawai ${ }^{\top}$ i, National Foreign Language Resource Center.

Brown, J. D., \& Kondo-Brown, K. (Eds.). (2006). Perspectives on teaching connected speech to second language speakers. Honolulu, HI: University of Hawai 'i, National Foreign Language Resource Center.

Call. M. E. (1985). Auditory short-term memory, listening comprehension, and the input hypothesis. TESOL Quarterly, 19(4), 765-781.

Campbell, D., Meinardi, M., Richardson, B., Macdonnell, C. (2007). The need for a speech courpse. Available: http://arrow.dit.ie/cgi/viewcontent.cgi?article $=1035 \&$ context $=$ dmccon

Carreira, J.M. (2008). Effects of teaching reduced forms in a university preparatory course. In K. Bradford Watts, T. Muller, \& M. Swanson (Eds.), JALT2007 Conference Proceedings (pp.200-207). Tokyo: JALT. 
Cauldwell, R. (2003). Streaming Speech: Listening and Pronunciation for Advanced Learners of English, Birmingham: speech inaction.

Field, J. (2003). Promoting perception: lexical segmentation in L2 listening, ELT Journal, Vol. 57(4), 325-334

Henrichsen, L. (1984). Sandhi-variation: A filter of input for learners of ESL. Language Learning, 34(3), 103-126.

Ito, Y. (2006a). The comprehension of English reduced forms by second language learners and its effect on input-intake process. In J. D. Brown, \& K. Kondo-Brown, (Eds.), Perspectives on teaching connected speech to second language speakers (pp. 67-81). Honolulu, HI: University of Hawai'i, National Foreign Language Resource Center.

Ito, Y. (2006b). The significance of reduced forms in L2 pedagogy. In J. D. Brown, \& K. Kondo-Brown, (Eds.), Perspectives on teaching connected speech to second language speakers (pp. 17-25). Honolulu, HI: University of Hawaii, National Foreign Language Resource Center.

Kenworthy, J. (1987). Teaching English Pronunciation Longman

Leow, R. (1997). Attention, awareness, and foreign language behavior. Language Learning, 47(3), 467_505.

Lund, R. J. (1991). A comparison of second language listening and reading comprehension. The Modern Language Journal, 75(2), 196-204.

Lynch, T. (1998).Theoretical perspectives on listening. Annals Review of Applied Linguistics. 18, 3-19.

Matsuzawa, T. (2006). Comprehension of English reduced forms by Japanese business people and the effectiveness of instruction. In J. D. Brown, \& K. Kondo-Brown, (Eds.), Perspectives on teaching connected speech to second language. (pp.59-66). Honolulu, HI: University of Hawai'i, National Foreign Language Resource Center.

Mendelsohn, D. J. (1984). There ARE strategies for listening. TEAL Occasional Papers, 8, 63-76.

Meyer, R. (1984). "Listen my children and you shall hear ..." Foreign Language Annals, 17(4), 343-344.

Norris, R. W. (1995). Teaching Reduced Forms: Putting the Horse Before the Cart. In English Teaching Forum, Vol. 33(3), 47-50.

Nunan, D. (1997). Listening in language learning. Paper presented at the Korea TESOL Convention, Kyongju, Korea, October 1997.

Osada, N. (2004). Listening comprehension research: A brief review of the past thirty years. Dialogue, 3, 53-66.

Oxford, R. L. (1993). Research update on teaching listening. System, 21(2), 205-211.

Rivers, W. (1966). Listening comprehension. The Modern Language Journal, 50(4), 196- 204.

Pallant, J. (2007). SPSS survival manual: A Step by Step Guide to Data Analysis Using SPSS. Opening University Press. Rosa (2002). A survey of ESL teachers' perspectives on reduced forms instruction. University of Hawai'i at Mānoa.

Rosa, E. and O'Neill, D. (1999). Explicitness, intake, and the issue of awareness: Another piece to the puzzle. Studies in Second Language Acquisition, 21(4), 511_553.

Rost, M. (1994). Introducing listening. London: Penguin.

Skinner, B. F., 1957. Verbal Behavior. New York: Appleton Century Croft.

Seong, Y. H. (2008). Evaluating an instrument for assessing connected speech performance using facets analysis. University of Hawai'i at Mānoa. Second Language Studies, 26(2), 45-101.

Ur, P. (1984). Teaching listening comprehension. Cambridge, NY: Cambridge University Weinstein, N. 2001. Whaddaya Say? (2nd ed.). White Plains, NY: Pearson Education.

Williams, J. (1999). Memory, attention and inductive learning. Studies in Second Language Acquisition, 21(1), 1_48.

Williams, J. (2005). Learning with awareness. Studies in Second Language Acquisition, 27(2), 269_304.

Williams, J. and Lovatt, P. (2003). Phonological memory and rule learning. Language Learning, 53(1), 67_121. 